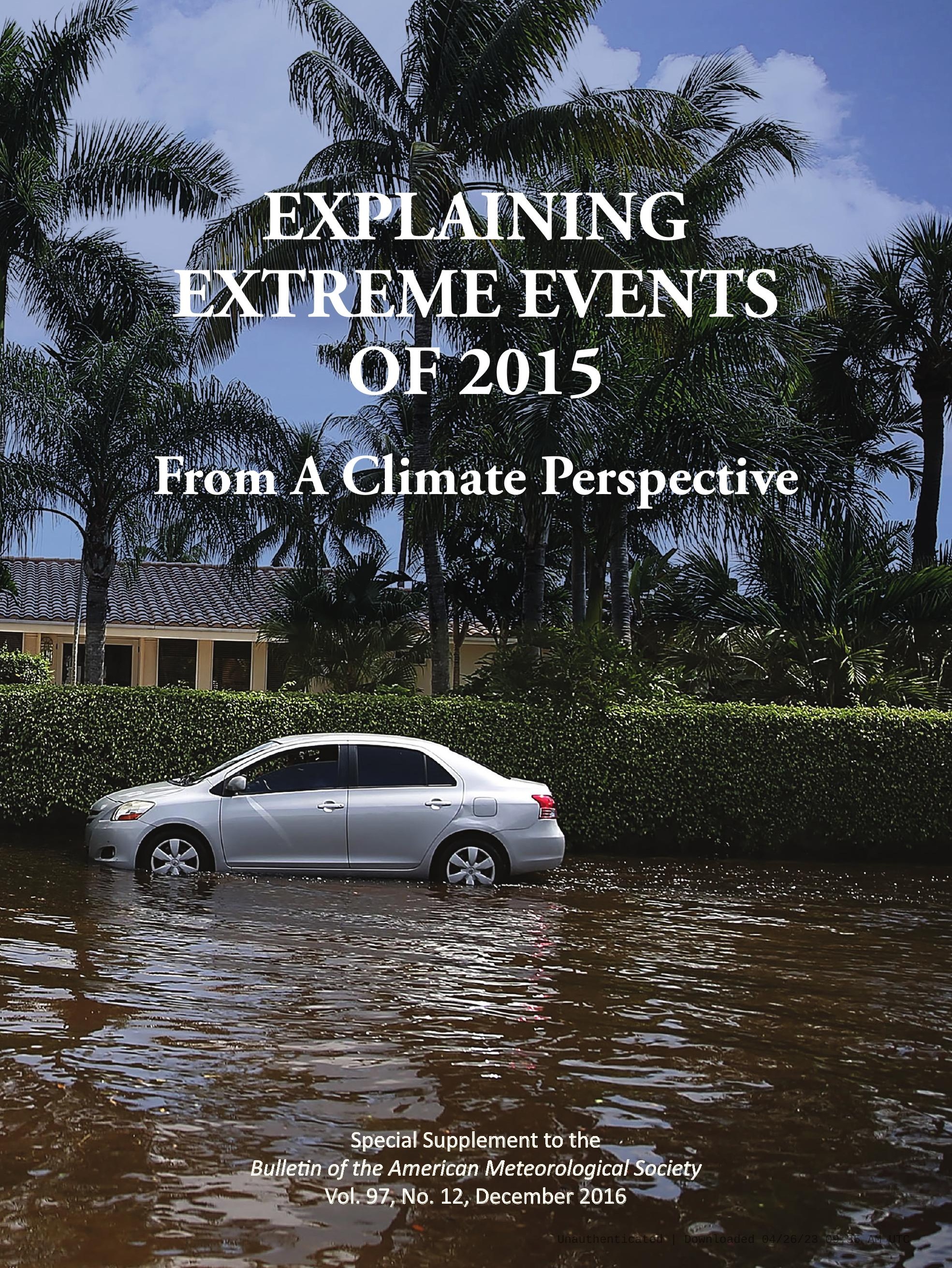




\section{EXPLAINING EXTREME \\ EVENTS OF 20I5 FROM A \\ CLIMATE PERSPECTIVE}

\section{Editors}

Stephanie C. Herring, Andrew Hoell, Martin P. Hoerling, James P. Kossin,

Carl J. Schreck III, and Peter A. Stott

Special Supplement to the

Bulletin of the American Meteorological Society

Vol. 97, No. 12, December 2016

American Meteorological Society 


\section{CORRESPONDING EDITOR:}

Stephanie C. Herring, PhD

NOAA National Centers for Environmental Information

325 Broadway, E/CC23, Rm IB-I3I

Boulder, CO, 80305-3328

E-mail: stephanie.herring@noaa.gov

\section{Cover CRedit:}

CPhoto by Joe Raedle/Getty Images-A vehicle drives through flooded streets caused by a combination of the lunar orbit which caused seasonal high tides and what many believe is the rising sea levels due to climate change on September 30, 20I5, in Fort Lauderdale, Florida. South Florida is projected to continue to feel the effects of climate change, and many of the cities have begun programs such as installing pumps or building up sea walls to try and combat the rising oceans.

\section{HOW TO CITETHIS DOCUMENT}

Citing the complete report:

Herring, S. C., A. Hoell, M. P. Hoerling, J. P. Kossin, C. J. Schreck III, and P.A. Stott, Eds., 20I6: Explaining Extreme Events of 2015 from a Climate Perspective. Bull.Amer. Meteor. Soc., 97 (I 2), SI-SI 45.

Citing a section (example):

Partain, J. L., and Coauthors, 2016: An assessment of the role of anthropogenic climate change in the Alaska fire season of 2015 [in "Explaining Extremes of 2015 from a Climate Perspective"]. Bull. Amer. Meteor. Soc., 97 (I2), SI4-SI8, doi:I0.II75/BAMS-D-16-0149.

\section{EDITORIAL AND PRODUCTION TEAM}

Riddle, Deborah B., Lead Graphics Production, NOAA/NESDIS National Centers for Environmental Information,

Asheville, NC

Veasey, Sara W., Visual Communications Team Lead, NOAA/ NESDIS National Centers for Environmental Information, Asheville, NC

Love-Brotak, S. Elizabeth, Graphics Support, NOAA/NESDIS National Centers for Environmental Information,

Asheville, NC

Fulford, Jennifer, Editorial Support, Telesolv Consulting LLC, NOAA/NESDIS National Centers for Environmental Information, Asheville, NC

Griffin, Jessicca, Graphics Support, Cooperative Institute for Climate and Satellites-NC, North Carolina State University, Asheville, NC
Maycock, Tom, Editorial Support, Cooperative Institute for Climate and Satellites-NC, North Carolina State University, Asheville, NC

Misch, Deborah J., Graphics Support, Telesolv Consulting LLC, NOAA/NESDIS National Centers for Environmental Information, Asheville, NC

Osborne, Susan, Editorial Support, Telesolv Consulting LLC, NOAA/NESDIS National Centers for Environmental Information, Asheville, NC

Sprain, Mara, Editorial Support, LAC Group, NOAA/NESDIS National Centers for Environmental Information, Asheville, NC

Young, Teresa, Graphics Support, STG, Inc., NOAA/NESDIS National Centers for Environmental Information, Asheville, NC 


\section{TABLE OF CONTENTS}

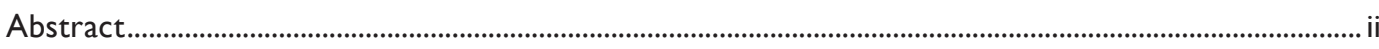

I. Introduction to Explaining Extreme Events of 2015 from a Climate Perspective.................................

2. Multimodel Assessment of Anthropogenic Influence on Record Global and Regional Warmth

During 2015 .......................................................................................................................................

3. What History Tells Us About 2015 U.S. Daily Rainfall Extremes ......................................................

4. An Assessment of the Role of Anthropogenic Climate Change in the Alaska Fire Season

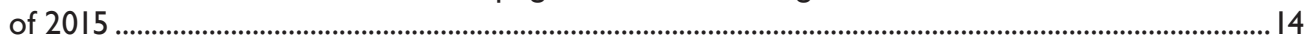

5. The 2014/15 Snowpack Drought in Washington State and its Climate Forcing ................................19

6. In Tide's Way: Southeast Florida's September 2015 Sunny-day Flood ................................................. 25

7. Extreme Eastern U.S. Winter of 2015 Not Symptomatic of Climate Change .....................................

8. The Role of Arctic Sea Ice and Sea Surface Temperatures on the Cold 2015 February

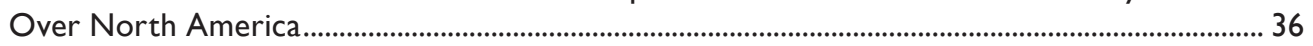

9. The 2015 Extreme Drought in Western Canada ................................................................................ 42

10. Human Contribution to the Record Sunshine of Winter 2014/15 in the United Kingdom .............47

II. The Role of Anthropogenic Warming in 2015 Central European Heat Waves ...................................5I

12. The 2015 European Heat Wave ....................................................................................................................

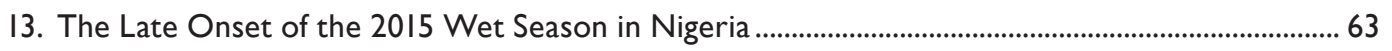

14. Human Influences on Heat-Related Health Indicators During the 2015 Egyptian Heat Wave .................................................................................................................................. 70

15. Assessing the Contributions of Local and East Pacific Warming to the 2015

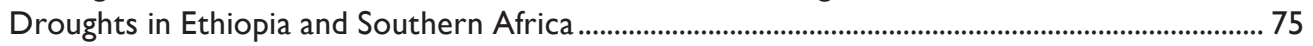

16. The Deadly Combination of Heat and Humidity in India and Pakistan in Summer 2015..................8I

17. The Heavy Precipitation Event of December 2015 in Chennai, India................................................... 87

18. Attribution of Extreme Rainfall in Southeast China During May 2015 ............................................. 92

19. Record-Breaking Heat in Northwest China in July 2015: Analysis of the Severity and Underlying Causes ......................................................................................................................... 97

20. Human Influence on the 2015 Extreme High Temperature Events in Western China................... 102

21. A Persistent Japanese Heat Wave in Early August 2015: Roles of Natural Variability and

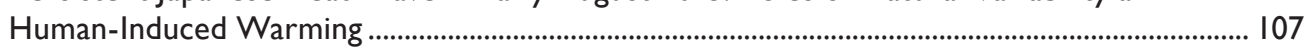

22. Climate Change and El Niño Increase Likelihood of Indonesian Heat and Drought........................ 113

23. Southern Australia's Warmest October on Record: The Role of ENSO and Climate Change....................................................................................................................................... 118

24. What Caused the Record-Breaking Heat Across Australia in October 2015? .............................. 122

25. The Roles of Climate Change and El Niño in the Record Low Rainfall in October 2015 in Tasmania, Australia.

26. Influences of Natural Variability and Anthropogenic Forcing on the Extreme 2015 Accumulated Cyclone Energy in the Western North Pacific

27. Record Low Northern Hemisphere Sea Ice Extent in March 2015 .............................................. 136

28. Summary and Broader Context.....................................................................................................141 
This fifth edition of explaining extreme events of the previous year (2015) from a climate perspective continues to provide evidence that climate change is altering some extreme event risk. Without exception, all the heat-related events studied in this year's report were found to have been made more intense or likely due to human-induced climate change, and this was discernible even for those events strongly influenced by the $2015 \mathrm{El}$ Niño. Furthermore, many papers in this year's report demonstrate that attribution science is capable of separating the effects of natural drivers including the strong 2015 El Niño from the influences of long-term human-induced climate change.

Other event types investigated include cold winters, tropical cyclone activity, extreme sunshine in the United Kingdom, tidal flooding, precipitation, drought, reduced snowpack in the U.S. mountain west, arctic sea ice extent, and wildfires in Alaska. Two studies investigated extreme cold waves and monthly-mean cold conditions over eastern North America during 2015, and find these not to have been symptomatic of human-induced climate change. Instead, they find the cold conditions were caused primarily by internally generated natural variability. One of these studies shows winters are becoming warmer, less variable, with no increase in daily temperature extremes over the eastern United States. Tropical cyclone activity was extreme in 2015 in the western North Pacific (WNP) as measured by accumulated cyclone energy (ACE). In this report, a study finds that human-caused climate change largely increased the odds of this extreme cyclone activity season. The 2015 Alaska fire season burned the second largest number of acres since records began in 1940. Investigators find that human-induced climate change has increased the likelihood of a fire season of this severity.

Confidence in results and ability to quickly do an attribution analysis depend on the "three pillars" of event attribution: the quality of the observational record, the ability of models to simulate the event, and our understanding of the physical processes that drive the event and how they are being impacted by climate change. A result that does not find a role for climate change may be because one or more of these three elements is insufficient to draw a clear conclusion. As these pillars are strengthened for different event types, confidence in the presence and absence of a climate change influence will increase.

This year researchers also link how changes in extreme event risk impact human health and discomfort during heat waves, specifically by looking at the role of climate change on the wet bulb globe temperature during a deadly heat wave in Egypt. This report reflects a growing interest within the attribution community to connect attribution science to societal impacts to inform risk management through "impact attribution." Many will watch with great interest as this area of research evolves in the coming years. 


\title{
13. THE LATE ONSET OF THE 20I5 WET SEASON IN NIGERIA
}

\author{
Kamoru A. Lawal, Abayomi A. Abatan, Oliver Angélil, Eniola Olaniyan, Victoria H. Olusoji, \\ Philip G. Oguntunde, Benjamin Lamptey, Babatunde J. Abiodun, Hideo Shiogama, \\ Michael F. Wehner, and Dáithí A. Stone
}

\begin{abstract}
We find no evidence that the delayed onset of the wet season over Nigeria during April-May 2015 was made more likely by anthropogenic influences or anomalous sea surface temperatures.
\end{abstract}

Introduction. Nigeria experienced a delay in the onset of the wet season in 2015. Annually, the wet season in Nigeria starts with the steady advancement of the intertropical discontinuity [ITD-represented in this study by the average latitudinal position of $15^{\circ} \mathrm{C}$ dewpoint temperature contour line between longitude $2^{\circ}-15^{\circ} \mathrm{E}$ (www.cpc.ncep.noaa.gov/products /international/itf/itcz.shtml; Eldridge 1957; Buckle 1996; Pospichal et al. 2010; Fig. 13.1a)] from the south to the north (Nicholson and Grist 2003; Omotosho and Abiodun 2007; Omotosho 2008). The season usually begins around March or April in the southern parts $\left(4^{\circ}-8^{\circ} \mathrm{N}\right)$ of the country, commencing almost one-and-a-half months later in the northern parts $\left(8^{\circ} \mathrm{N}\right.$ northward: Ati et al. 2002; Oguntunde et al. 2014). In 2015, however, the northward progression of the onset of rainfall exhibited some anomalous behavior. In April, the ITD did not advance substantially from March, being more than $2^{\circ}$ south of its usual latitudinal position and also about $1^{\circ}$ south of the 10th percentile of its southernmost latitudinal position based on the 1981-2010 climatological period (Fig. 13.1a). Consequently, almost the entire country experienced April rains that were $40 \%$ below normal (Fig. 13.1b). The situation improved in the month of May when the southern and central regions

\begin{abstract}
AFFILIATIONS: LAWAL- Nigerian Meteorological Agency, Lagos, Nigeria; ABATAN-Department of Geological and Atmospheric Sciences, lowa State University, Ames, lowa; ANGÉLIL-University of New South Wales, Sydney, Australia; OlaniYan, OlusojI-Nigerian Meteorological Agency, Abuja, Nigeria; Oguntunde-Federal University of Technology, Akure, Nigeria; LAMPTEY - African Centre of Meteorological Application for Development, Niamey, Niger; ABIODUN-Department of Environmental and Geographical Sciences, University of Cape Town, Cape Town, South Africa; SHIOGAMA-National Institute for Environmental Studies, Tsukuba, Japan; WeHNER, StONELawrence Berkeley National Laboratory, Berkeley, California DOI:I0.II75/BAMS-D-I6-013I.I
\end{abstract}

A supplement to this article is available online (10.1175 /BAMS-D-|6-0I3I.2) experienced almost normal rainfalls (i.e., $\pm 20 \%$ ), but areas north of $10^{\circ} \mathrm{N}$ still experienced more than $40 \%$ rainfall deficits (Fig. 13.1c). Normal rainfall amounts arrived in the northern regions in June, even though the ITD remained about $2^{\circ}$ south of its climatological latitudinal positions from April to July (Fig. 13.1a). According to reports from farmers (e.g., Daily Post [Nigeria], 21 June 2015; Okojie 2015) and personal conversations with some stakeholders, there were widespread crop failures resulting from continuous irregular rainfall (Agbo et al. 2015). Consequently, socio-economic activities, food production, and water resources were negatively affected during the year because the rainfall and growing seasons started much later than expected. Although the economic implications of the delay in the onset of the 2015 wet season have not been quantified at the time of this report, the nation witnessed abrupt increases in the prices of food commodities, thereby affecting food security (www.foodsecurityportal.org/nigeria /indicators; Agbo et al. 2015).

With the growing confidence of users in climate models (which are used for planning in order to mitigate the threat of climate variability and change; Abiodun et al. 2012; Olaniyan et al. 2015), a number of questions arise: Can simulations of current generation atmosphere-land climate models capture the late onsets such as occurred in 2015 in Nigeria? What is the role of anomalous sea surface temperatures (SSTs), as well as anthropogenic interference in the climate system (or non-anthropogenic interference) in altering the chance of the 2015 late onset of the rainy season over Nigeria?

Data. In this study, we use daily rainfall and dewpoint observations from a network of more than 50 meteorological stations of the Nigerian Meteorological Agency (NiMet; www.nimet.gov.ng). We also analyze simulations conducted with the CAM5.1 
(a)
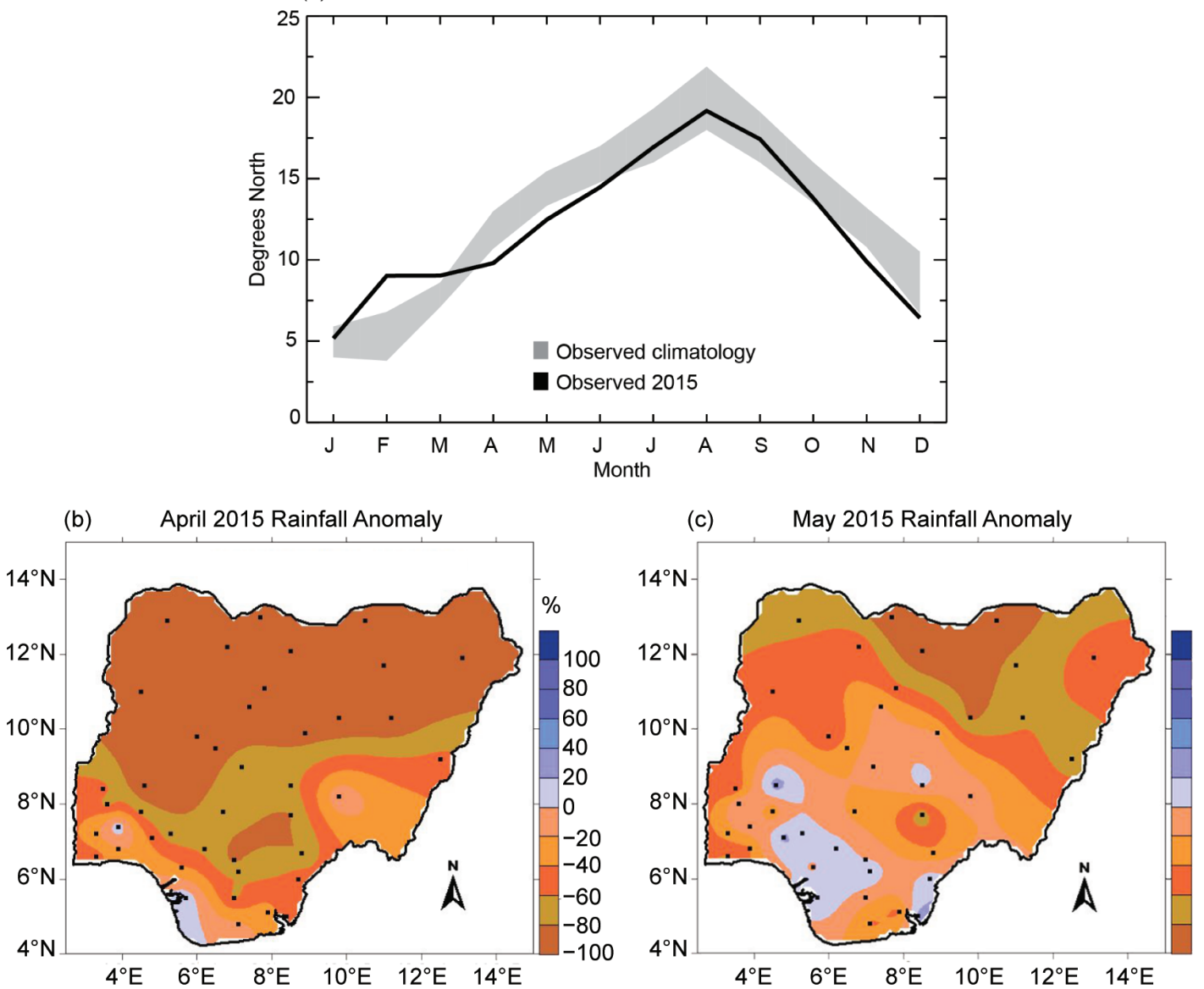

(d) April 2015 Observed SST Anomaly

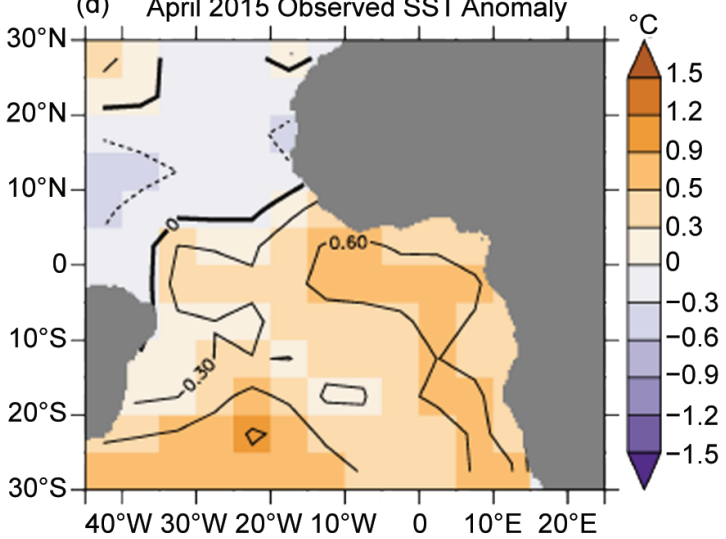

(e) May 2015 Observed SST Anomaly

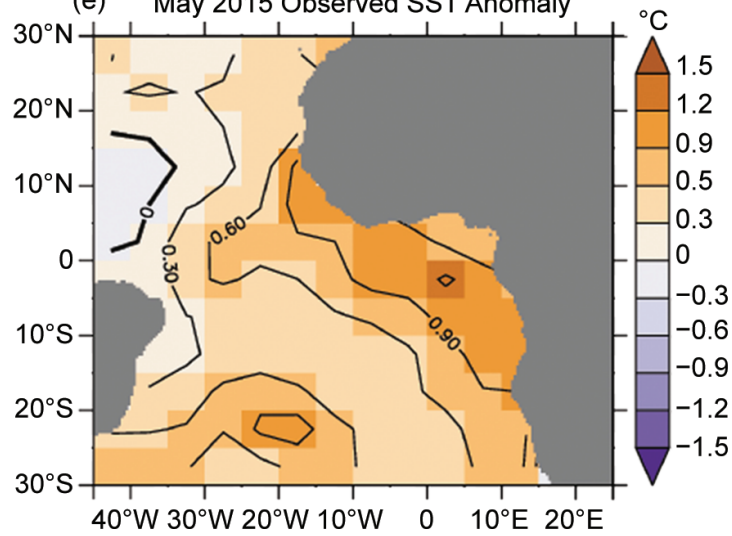

FIG.I3.I. (a) Observed mean monthly climatological and 2015 latitudinal positions of ITD over Nigeria; the gray shade represents the 10th-90th percentile range of the latitudinal positions of the ITD during the 198I-2010 period. Rainfall anomalies (\%) over Nigeria in (b) Apr and (c) May 20I5; the dots represent the location of all the synoptic meteorological stations used in the study while the brown colors indicate rainfall deficit. SST anomalies (shade and contour; ${ }^{\circ} \mathrm{C}$ ) over the Atlantic Ocean in (d) Apr and (e) May 2015.

(Neale et al. 2012) and MIROC5 (Watanabe et al. 2010) atmosphere-land climate models. CAM5.1 is run at $\sim 1.0^{\circ}$ spatial resolution, while MIROC5 is at $\sim 1.5^{\circ}$. Both models are run under the experimental protocol of the C20C+ Detection and Attribution Project (http://portal.nersc.gov/c20c; Stone 2013), with 99 and 100 simulations, respectively, run under observed (All-Hist) radiative, ocean surface, and 
land use/cover boundary conditions, and another 98 and 100 simulations, respectively, run under what those boundary conditions might have been in the absence of anthropogenic interference (Nat-Hist) (Angélil et al. 2016; Shiogama et al. 2013 and 2014). Nat-Hist anthropogenic forcings are set to circa year 1850 values, while observed ocean temperatures and sea ice are cooled by spatially- and time-varying amount based on atmosphere-ocean models in the CMIP5 archive (Stone and Pall 2016, unpublished manuscript). In addition to substantial algorithmic differences, there are some distinctions in the setup between the models: MIROC 5 uses prescribed aerosol precursor emissions, while CAM5.1 uses prescribed aerosol burdens, relevant here as simulated precipitation over West Africa can be sensitive to the regional aerosol forcing (Tompkins et al. 2005; Rosenfeld et al. 2008 and 2014). In addition, MIROC5 uses year1850 land cover for the Nat-Hist simulations, while CAM5.1 uses present-day land cover; land cover/use change is understood to have significant effects on rainfall and atmospheric variables such as midtropospheric wind speed, daily extreme temperatures, specific humidity, evapo-transpiration, etc., over Nigeria (Abiodun et al. 2008; Dirmeyer et al. 2010; Christidis et al. 2013). Given that monitoring of seasonal climate and the impacts of its variability over Nigeria is based on precipitation, we focus on April and May precipitation here. Anomalies are calculated from the 1981-2010 precipitation climatology for all data sources. Furthermore, ITD are calculated from the dewpoint observations obtained from NiMet data archive and from output of the CAM5.1 and MIROC5 simulations. Relative to the observed climatology, both models tend to have a northward bias in the ITD during the first half of the year, including the onset period, with the CAM5.1 ITD advancing a bit faster than observed during the onset season (Figs. 13.2a,b). Beyond this bias, the positions of the ITD in both models closely follow the observed climatological positions throughout the year, and the range of year-to-year variability is comparable to the observed range. Lawal (2015) found that CAM5.1 is capable of representing the dominant circulation processes during the wet season.

Results. The results from both models suggest that anthropogenic influences may have moderately (CAM5.1) or slightly (MIROC5) decreased the chance for low April rainfall and not altered the chances for low May rains (Table 13.1). The confidence intervals about these estimates however, are large, and the pos- sible difference in April drought frequencies could have resulted from random sampling. The estimates of the risk ratio (the ratio of the probabilities in 2015 between the All-Hist and Nat-Hist ensembles of being drier than the 10th percentile of the All-Hist simulations during the 1981-2010 periods) are less than 1.0 in April while the estimates are close to 1.0 in May (Table 13.1). In addition, the simulations suggest little spatial structure in the influence of anthropogenic emissions on the chance of low April-May 2015 precipitation (Figs. 13.2c-f); low risk ratios in the northern regions in April are not robust due to the low rainfall usually experienced there.

While anthropogenic influence may not have substantially affected the chance of the late onset, the influence of the naturally occurring anomalies in SSTs may be different. Figures 13.1d,e show that the observed SSTs (www.esrl.noaa.gov/psd/data /gridded/data.kaplan_sst.html; Kaplan et al. 1998;) over the Gulf of Guinea were warmer than normal during April-May 2015. Under these warmer-thannormal SST conditions, it should have been possible to advect sufficient moisture to support precipitation (Zheng et al. 1999; Odekunle and Eludoyin 2008). It would also be expected that the moisture laden southwesterly trade winds would have become more energized, buoyant, and capable of dynamically pushing the ITD deeply into the northern end of the country, thereby resulting in above-normal rainfall both at the coastal and inland parts of the country (Omotosho and Abiodun 2007). However, both models suggest that anomalous SSTs had little effect on the chance of low May 2015 precipitation while they indicate that anomalous SSTs might in fact have decreased the chance of low April 2015 precipitation over the country relative to amounts experienced during the previous eight years (risk ratio $-\mathrm{P}_{\text {All-Hist }} / \mathrm{P}_{2007-2014}$, with the 2007-14 period used because of the availability of 100 -member ensembles with both models; Table 13.1) and, in a statistically significant manner for CAM5.1, relative to the 1981-2010 climatology (not shown). This is consistent with the shift in ITD position in CAM5.1's All-Hist 2015 simulations relative to the 1981-2010 climatology (Fig. 13.2a).

The results for soil moisture are similar to those of SSTs (not shown). Both models suggest that both the anthropogenic emissions and anomalous SSTs decreased the chance of dry soil (upper $10 \mathrm{~cm}$ ) in May 2015, but they are also consistent with no influence. This suggests little effect of temperature on Nigerian soil moisture in a warming climate. Three possible explanations for this are: firstly, if it has not yet rained, 
(a)

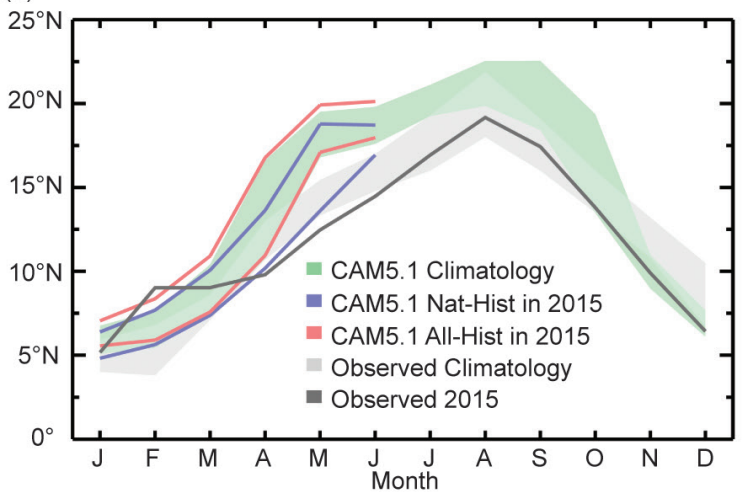

(c)

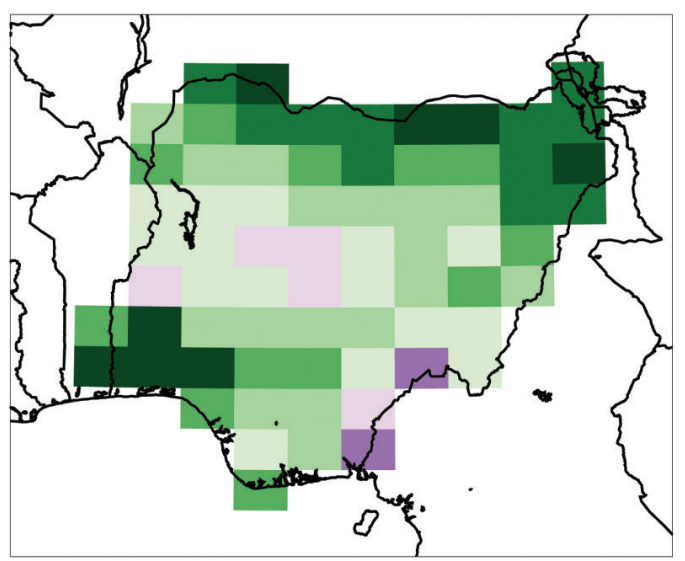

(e)

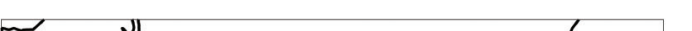

(b)

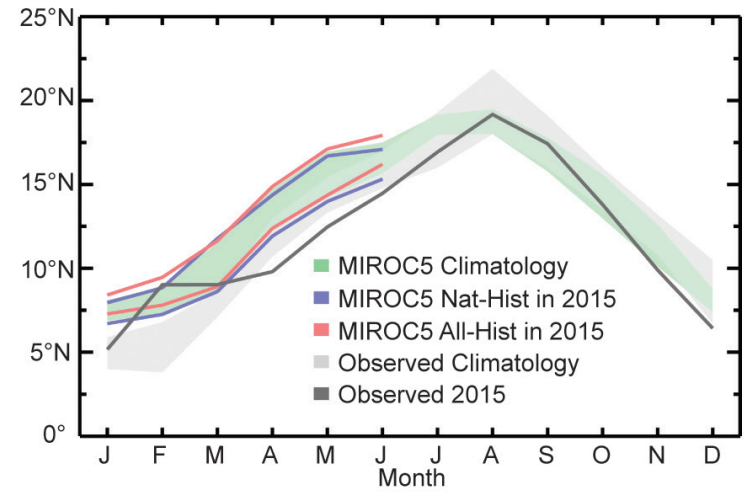

(d)

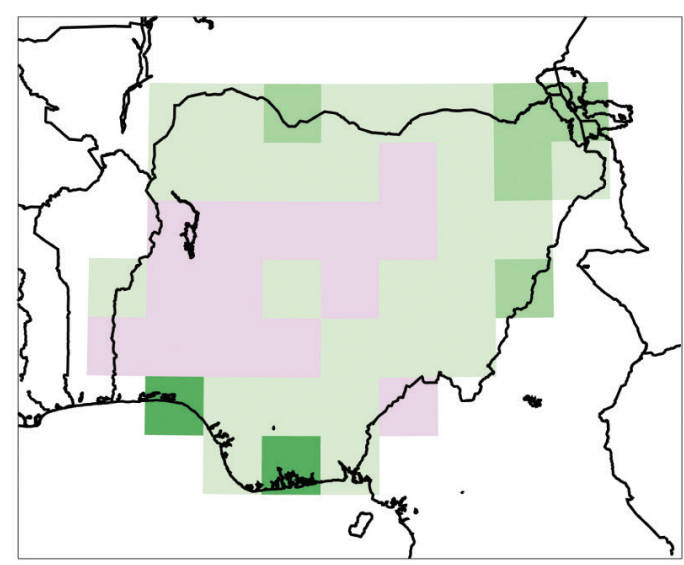

(f)

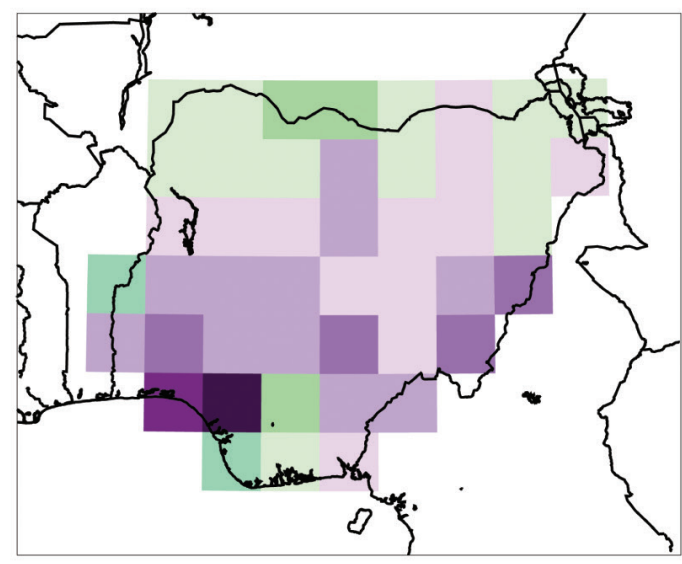

0.25

0.5

1

2

4

FIG. 13.2. Annual cycle of the ITD as simulated by (a) CAM5.I and (b) MIROC5. The I0th-90th percentile range of the 2015 All-Hist and Nat-Hist simulations are denoted by pairs of lines, with turquoise shade denoting the range from the 50 CAM5.I and 10 MIROC5 simulations covering the I98I-20I0 climatological period; observed values are reproduced from Fig. I3. Ia. (c),(f) The spatial structures of the risk ratio due to anthropogenic emissions for falling below the 10th percentile of 198I-20I0 simulated precipitation climatology in Apr and May 2015 over Nigeria from (c),(e) CAM5.I; (d),(f) MIROC5. Green colors indicate that the chance of a dry month has decreased due to emissions.

then there is no moisture to evaporate from the soil; secondly, if the rains have arrived, then the air is too moist to support evaporation, so there is no warm- ing effect on evaporation during these months; and lastly, the anthropogenic signal may be smaller than the internal variability of the soil moisture, that is, 
Table I3.I. Probability ( $P x)$ of being below the I0th percentile of precipitation over the I98I2010 period in the All-Hist and Nat-Hist ensembles, and the risk ratios for the anthropogenic influence (PALL-Hist/PNat-Hist) and for the influence of anomalous SSTs with respect to the previous 8 years (PALL-Hist/P2007-2014) for exceeding that threshold in Apr and May 2015 over Nigeria.

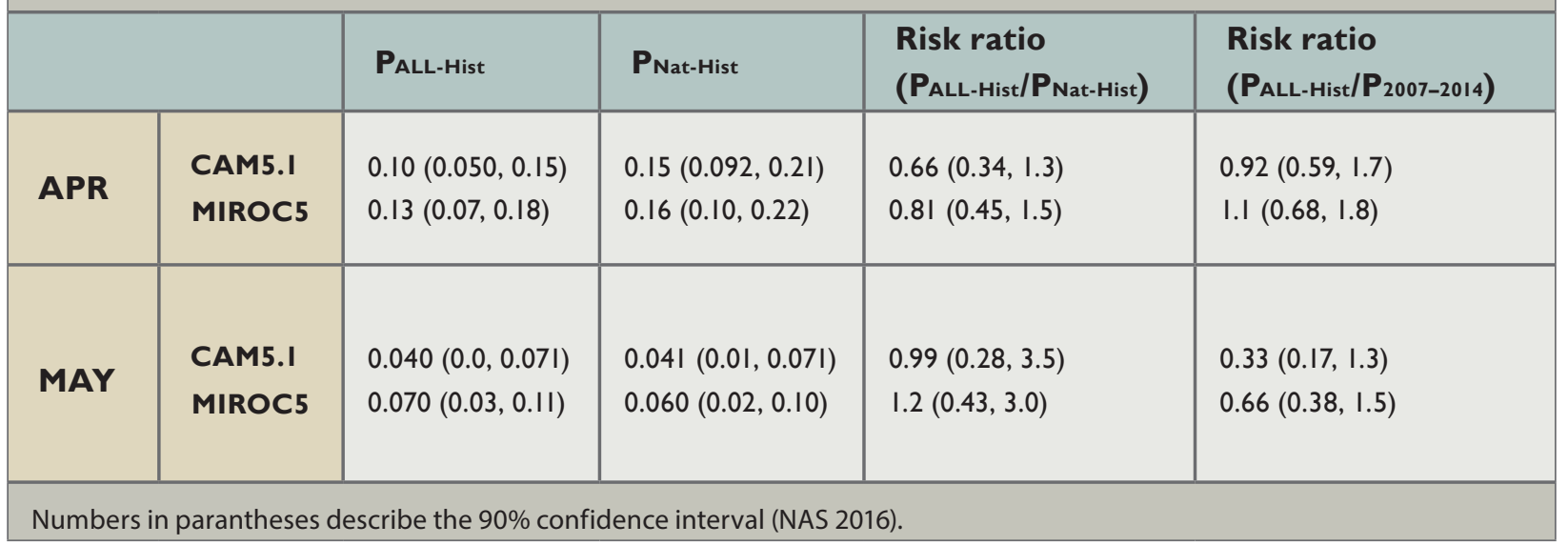

low signal-to-noise ratio. This contradicts the notion that mean warming dominates the impact of anthropogenic emissions on every extreme weather event (Trenberth et al. 2015).

Summary. The results from the climate models examined indicate that there is little or no evidence of anthropogenic emissions or anomalous SSTs on the delay in the onset of the 2015 wet season in Nigeria. In as much as the models do suggest an influence, the effect was, in fact, to make the late onset less likely and thus truly a fluke. The implication is that rainfall deficits observed over Nigeria during the April-May 2015 onset period were the results of unforced internal variability of the tropical atmosphere (see analyses in Supplemental Materials).

ACKNOWLEDGEMENTS. We appreciate the primary editor and other anonymous reviewers for their helpful comments and suggestions. We also thank NiMet, Japanese Research Community, and Lawrence Berkeley National Laboratory that provided observations and simulations datasets used in this study. Stone and Wehner were supported by the Regional and Global Climate Modeling Program (contract number DE-AC02- 05CH11231); Abatan by the U.S. National Science Foundation (grant number AGS-1243030); and Shiogama by the Program for Risk Information on Climate Change.

\section{REFERENCES}

Abiodun, B. J., J. S. Pal, E. A. Afiesimama, W. J. Gutowski, and A. Adedoyin, 2008: Simulation of West African monsoon using RegCM3 Part II: Impacts of deforestation and desertification. Theor. Appl. Climatol., 93, 245-261, doi:10.1007/s00704 -007-0333-1.

Abiodun, B. J., K. A. Lawal, A. T. Salami, A. A. Abatan, 2012: Potential influences of global warming on future climate and extreme events in Nigeria. Reg. Environ. Change, 13, 477-491, doi:10.1007/s10113 -012-0381-7.

Agbo, A. D., V. A. Yusuf, and A. Acholo, 2015: Nigeria: Poor harvest looms as irregular rainfall continues. All Africa for Daily Trust, 23 July 2015. [Available online at http://allafrica.com/stories/201507231260. html.]

Angélil, O., D. Stone, M. Wehner, C. J. Paciorek, H. Krishnan, and W. Collins, 2016: An independent assessment of anthropogenic attribution statements for recent extreme weather. J. Climate, in press, doi:10.1175/JCLI-D-16-0077.1.

Ati, O. F., C. J. Stigter, and E. O. Oladipo, 2002: A comparison of methods to determine the onset of growing season in Northern Nigeria. Int. J. Climatol., 22, 731-742, doi:10.1002/joc.712.

Bai, P., W. Gan, and L. Shi, 2011: Bayesian confidence interval for the risk ratio in a correlated $2 \times 2$ table with structural zero. J. Appl. Stat., 38, 2805-2817, doi:10.1080/02664763.2011.570318. 
Buckle, C., 1996: Weather and Climate in Africa. Addison-Wesley Longman, $312 \mathrm{pp}$.

Christidis, N., P. A. Stott, G. C. Hegerl, and R. A. Betts, 2013: The role of land use change in the recent warming of daily extreme temperatures. Geophys. Res. Lett., 40, 589-594, doi:10.1002/grl.50159.

Dirmeyer, P. A., D. Niyogi, N. de Noblet-Ducoudré, R. E. Dickinson, and P. K. Snyder, 2010: Impacts of land use change on climate. Int. J. Climatol., 30, 1905-1907, doi:10.1002/joc.2157.

Eldridge, R. H., 1957: A synoptic study of West African disturbance lines. Quart. J. Roy. Meteor. Soc., 83 303-314.

Kaplan, A., M. Cane, Y. Kushnir, A. Clement, M. Blumenthal, and B. Rajagopalan, 1998: Analyses of global sea surface temperature 1856-1991. J. Geophys. Res., 103 (C9), 18567-18589.

Lawal, K. A., 2015: Understanding the variability and predictability of seasonal climates over West and Southern Africa using climate models. PhD thesis, Faculty of Science, University of Cape Town, Cape Town, South Africa. [Available online at https:// open.uct.ac.za/handle/11427/16556.]

Kuonen D., 2006: Studentized bootstrap confidence intervals based on M-estimates. J. Appl. Stat., 32, 443-460, doi:10.1080/02664760500079340.

NAS, 2016: Attribution of Extreme Weather Events in the Context of Climate Change. National Academies Press, 186 pp., doi:10.17226/21852.

Nicholson, S. E., and J. P. Grist, 2003: The seasonal evolution of the atmospheric circulation over West Africa and equatorial Africa. J. Climate, 16, 1013-1030.

Neale, R. B., and Coauthors, 2012: Description of the NCAR Community Atmosphere Model (CAM 5.0). NCAR Tech. Note, NCAR/TN-486+STR, 274 pp. [Available online at www.cesm.ucar.edu/models /cesm1.0/cam/docs/description/cam5_desc.pdf.]

Odekunle, T. O., and A. O. Eludoyin, 2008: Sea surface temperature patterns in the Gulf of Guinea: Their implications for the spatio-temporal variability of precipitation in West Africa. Int. J. Climatol., 28, 1507-1517, doi:10.1002/joc.1656.

Oguntunde, P. G., G. Lischeid, B. J. Abiodun, and O. Dietrich, 2014: Analysis of spatial and temporal patterns in onset, cessation and length of growing season in Nigeria. Agric. For. Meteor., 194, 77-87, doi:10.1016/j.agrformet.2014.03.017.
Okojie, J., 2015: Climate change threatens food production in Nigeria. Business Day, 5 August 2015. [Available online at http://businessdayonline.com /climate-change-threatens-food-production-in -nigeria/.]

Olaniyan, E., E. Afiesimama, F. Oni, and K. A. Lawal, 2015: Simulating the daily evolution of West African monsoon using high resolution regional COSMOmodel: A case study of the first half of 2015 over Nigeria. J. Climatol. Wea. Forecasting, 3, 142, doi:10.4172/2332-2594.1000142.

Omotosho, J. B., 2008: Pre-rainy season moisture build-up and storm precipitation delivery in the West Africa Sahel. Int. J. Climatol., 28, 937-946, doi:10.1002/joc.1548.

—_, and B. J. Abiodun, 2007: A numerical study of moisture build-up and rainfall over West Africa. Meteor. Appl., 14, 209-225, doi:10.1002/met.11.

Pospichal, B., D. Bou Karam, S. Crewell, C. Flamant, A. Hünerbein, O. Bock, and F. Saïd, 2010: Diurnal cycle of the intertropical discontinuity over West Africa analysed by remote sensing and mesoscale modelling. Quart. J. Roy. Meteor. Soc., 136 (Suppl. 1), 92-106, doi:10.1002/qj.435.

Rosenfeld, D., U. Lohmann, G. B. Raga, C. D. O’Dowd, M. Kulmala, S. Fuzzi, A. Reissell, and M. O. Andreae, 2008: Flood or drought: How do aerosols affect precipitation? Science, 321, 1309-1313, doi:10.1126 /science.1160606.

—_ and Coauthors, 2014: Global observations of aerosol-cloud-precipitation-climate interactions. Rev. Geophys., 52, 750-808, doi:10.1002/2013RG000441.

Shiogama, H., M. Watanabe, Y. Imada, M. Mori, M. Ishii, and M. Kimoto, 2013: An event attribution of the 2010 drought in the South Amazon region using the MIROC5 model. Atmos. Sci. Lett., 14, 170-175, doi:10.1002/asl2.435.

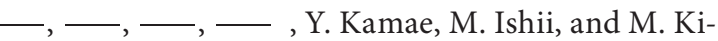
moto, 2014: Attribution of the June-July 2013 heat wave in the southwestern United States. SOLA, 10, 122-126, doi:10.2151/sola.2014-025.

Stone, D., 2013: Boundary conditions for the C20C Detection and Attribution Project: The All-Hist lest 1 and Nat-Hist/CMIP5-est1 scenarios. Lawrence Berkeley National Laboratory, 18 pp. [Available online at http://portal.nersc.gov/c20c /input_data/C20C-DandA_dSSTs_All-Hist-est1 _Nat-Hist-CMIP5-est1.pdf.] 
Tompkins, A. M., C. Cardinali, J.-J. Morcrette, and M. Rodwell, 2005: Influence of aerosol climatology on forecasts of the African Easterly Jet. Geophys. Res. Lett., 32, L10801, doi:10.1029/2004GL022189.

Trenberth, K. E., J. T. Fasullo, and T. G. Shepherd, 2015: Attribution of climate extreme events. Nat. Climate Change, 5, 725-730, doi:10.1038/nclimate2657.

Watanabe, M., and Coauthors, 2010: Improved climate simulation by MIROC5: Mean states, variability, and climate sensitivity. J. Climate, 23, 6312-6335, doi:10.1175/2010JCLI3679.1.

Zheng, X., E. A. B. Eltahir, and K. A. Emanuel, 1999: A mechanism relating tropical Atlantic Spring sea surface temperature and West African rainfall. Quart. J. Roy. Meteor. Soc., 125, 1129-1163. 


\section{Table 28.I. Summary of Results}

\section{ANTHROPOGENIC INFLUENCE ON EVENT}

\begin{tabular}{|c|c|c|c|}
\hline & INCREASE & DECREASE & NOT FOUND OR UNCERTAIN \\
\hline Heat & $\begin{array}{l}\text { Global Temperature (Ch. 2) } \\
\text { South India \& Sri Lanka (Ch. 2) } \\
\text { Central Europe (Ch. II) } \\
\text { Europe (Ch. I2) } \\
\text { Ethiopia and Southern Africa (Ch. I5) } \\
\text { N.W. China (Ch. I9) } \\
\text { W. China (Ch. 20) } \\
\text { Japan (Ch. 2I) } \\
\text { Indonesia (Ch. 22) } \\
\text { S. Australia (Ch. 23) } \\
\text { Australia (Ch. 24) }\end{array}$ & & Central Equitorial Pacific (Ch. 2) \\
\hline Cold & & Northeastern U.S. (Ch. 7) & $\begin{array}{l}\text { Mid-South Atlantic U.S. (Ch. 7) } \\
\text { N. America (Ch. 8) }\end{array}$ \\
\hline $\begin{array}{l}\text { Heat \& } \\
\text { Humidity }\end{array}$ & $\begin{array}{l}\text { Egypt (Ch. I4) } \\
\text { India \& Pakistan (Ch. 16) }\end{array}$ & & \\
\hline Dryness & $\begin{array}{l}\text { Indonesia (Ch. 22) } \\
\text { Tasmania (Ch. 25) }\end{array}$ & & \\
\hline $\begin{array}{l}\text { Heavy } \\
\text { Precipitation }\end{array}$ & China (Ch. I8) & & $\begin{array}{l}\text { Nigeria (Ch. I3) } \\
\text { India (Ch. I7) }\end{array}$ \\
\hline Sunshine & United Kingdom (Ch. I0) & & \\
\hline Drought & $\begin{array}{l}\text { Canada (Ch. 9) } \\
\text { Ethiopia and Southern Africa (Ch. I5) }\end{array}$ & & \\
\hline $\begin{array}{l}\text { Tropical } \\
\text { Cyclones }\end{array}$ & Western North Pacific (Ch. 26) & & \\
\hline Wildfires & Alaska (Ch. 4) & & \\
\hline $\begin{array}{l}\text { Sea Ice } \\
\text { Extent }\end{array}$ & & Arctic (Ch. 27) & \\
\hline $\begin{array}{l}\text { HIGH TIDE } \\
\text { FLOODS }\end{array}$ & SOUtheastern U.S. (CH. 6) & & \\
\hline $\begin{array}{l}\text { SNOWPACK } \\
\text { DROUGHT }\end{array}$ & WASHINGTON U.S. (CH. 5) & & \\
\hline TOTAL & 23 & 2 & 5 \\
\hline
\end{tabular}




\section{METHOD USED}

Heat

Ch. 2: CMIP5 modeling

Ch. II: Observations; weather@home modeling

Ch. 12: HadGEM3-A modeling

Ch. 15: CMIP5 modeling

Ch. 19: CMIP5 modeling with ROF; FAR

Ch. 20: CMIP5 modeling with ROF; FAR

Ch. 21: MIROC5-AGCM modeling

Ch. 22: Observations; CMIP5 modeling

Ch. 23: weather@home modeling; FAR

Ch. 24: BoM seasonal forecast attribution system and seasonal forecasts

Ch. 7: Observations; CMIP5 modeling

Ch. 8: AMIP (IFS model) modeling

Heat \&

Ch. 14: weather@home modeling

Humidity

Ch. 16: Non-stationary EV theory; C20C+ Attribution Subproject

Dryness

Ch. 22: Observations; CMIP5 modeling

Ch. 25: Observations; Modeling with CMIP5 and weather@home

Ch. 13: Observations; Modeling with CAM5.I and MIROC5

Heavy

Precipitation

Ch. 17: Observations; Modeling with weather@home, EC-Earth and CMIP5

Ch. 18: HadGEM3-A-N216 modeling; FAR

Sunshine

Ch. 10: Hadley Centre event attribution system built on the high-resolution version of HadGEM3-A

Ch. 9: Observations; CMIP5 modeling; Trend and FAR analyses

Drought

Ch. 15: CMIP5 modeling, land surface model simulations, and statistical analyses

Tropical

Cyclones

Ch. 26: GFDL FLOR modeling; FAR

Wildfires

Ch. 4: WRF-ARW optimized for Alaska with metric of fire risk (BUI) to calculate FAR

Sea Ice

Extent

HIGH TIDE

FLOODS

SNOWPACK

DROUGHT

Ch. 27: OGCM modeling

CH. 6: Tide-gauge data; Time-dependent EV statistical model

Ch. 5: Observations; CESMI modeling

\section{ACRONYMS:}

AMIP: Atmospheric Model Intercomparison Project

BoM: Bureau of Meteorology, Australia

BUI: Buildup Index

CAM: Community Atmosphere Model, http:www.cesm.ucar.edu

CESM: Community Earth System Model

CMIP: Coupled Model Intercomparison Project

FAR: Fraction of Attributable Risk

EC-EARTH: https://verc.enes.org/

EV: Extreme Value
GFDL FLOR: Geophysical Fluid Dynamics Laboratory Forecast version Low Ocean Resolution

GHCN: Global Historical Climatology Network

IFS: Integrated Forecast System

MIROC5-AGCM: Model for Interdisciplinary Research on ClimateAtmospheric General Circulation Model

OGCM: Ocean General Circulation Model

ROF: Regularized Optimal Fingerprinting

weather@home: http:www.climateprediction.net/weatherathome

WRF-ARW: Advanced Research (ARW) version of the Weather Research and Forecasting (WRF) model 